Research Article

\title{
Economic Analysis of Sweet Orange in Sindhuli District of Nepal
}

\author{
Dipika Parajulee $^{1 *}$, Apekshya Kandel ${ }^{1}$, Sangam Panta ${ }^{2}$, Kedar Devkota ${ }^{2}$ \\ ${ }^{1}$ Nepal Polytechnic Institute (NPI), Purbanchal University- Chitwan, Nepal \\ ${ }^{2}$ Agriculture and Forestry University (AFU) - Chitwan, Nepal
}

Article Information
Received: 19 June 2021
Revised version received: 19 July 2021
Accepted: 21 July 2021
Published: 29 July 2021
Cite this article as:
D. Parajulee et al. (2021) Int. J. Soc. Sc. Manage.
8(3): $396-400$. DOI: $10.3126 /$ ijssm.v8i3.38504
*Corresponding author
Dipika Parajulee,
Nepal Polytechnic Institute (NPI), Purbanchal
University- Chitwan, Nepal
Email: parajuleedipika423@gmail.com
Peer reviewed under authority of IJSSM
C) 2021 IJSSM, Permits unrestricted use under the
CC-By-NC license.
OPEN 9 ACCESS
This is an open access article \& it is licensed under a
International
(https://creativecommons.org/licenses/by-nc/4.0/)
Keywords: Ecomo

\begin{abstract}
Sweet orange is one of the major fruit grown in mid-hills of Nepal. It ranks $2^{\text {nd }}$ among the citrus fruits in terms of area and production after mandarin. The study depicts the socio economic aspect of sweet orange production in Sindhuli district.Data were collected from 60 randomly selected sweet orange growers from Tinkanya and Baseswor of Golanjor rural municipality using semi-structured interview schedule. Two FGD's was done in those places for the triangulation of household survey.Analysis was done using SPSS and excel. Socio demographic studies revealed that majorly (93.3\%), of growers were engaged in sweet orange farming. Most of the growers (98.3\%) had agriculture as their major occupation. The average land holdings of the farmers was 0.53 ha in which 0.37 ha of land was occupied for sweet orange cultivation. The average sweet orange production of total sixty households was calculated to be $1981.83 \mathrm{~kg} / \mathrm{ha}$. The total cost of Rs. 25797.36/ha was estimated and the gross return from the production was Rs.72634/ha; the benefit cost ratio was found to be 2.81 which supports that sweet orange production is being a profitable farming business. Furthermore, insects attack followed by irrigation problems and difficulty in transportation followed by lack of market price information were the major problems found in the production and marketing of sweet orange respectively. There is a high potentiality of increasing the fruit productivity if the constraints against the sweet orange cultivation are addressed properly and adequately.
\end{abstract}

Keywords: Economic; Sweet Orange; Production; Marketing; B: C ratio

\section{Introduction}

Citrus is one of the major cash generating fruit crops in midhills of Nepal and also recognized as high value crop under Agriculture Perspective Plan (APP). Citrus is not just a single fruit that covers a large range of fruits and is adaptable to varied range of area (Ghimire et al., 2006). Citrus fruit covers about $22 \%$ of total fruit area and production and majorly hilly region is dominant for the production of citrus fruits (Pandey et al., 2017). Sweet orange (Junar) is one of the most grown important fruit crops among the citrus along with mandarins, limes, lemons and grape fruits. Among the citrus, it is reported to be cultivated in about 114 countries of the world (Sefoka, 2012). It is successfully grown in 47 districts of Nepal.

Sweet orange is one of the leading fruits growing in midhills of Nepal and is gaining huge popularity among the farmers in recent years (Subedi et al., 2002). It has unique sweet taste and considered as special fruit of Nepal so, it can be expressed as national fruit of Nepal (Tomiyasu et al., 
1998). The productive land for sweet orange production in Nepal is 3443 ha with production 33558 metric ton (MT) and productivity of 9.7 ton/hectare (MoAD, 2016). The geographic position and climate of Sindhuli district which lies in inner Terai region of Nepal favors the large number of production and farmers are keenly interested to grow to meet the consumer's demand. It can be used for the preparation of jam, jelly, marmalade, cold drinks, and sauce which directly invites many manufacturing industries and generates employment for huge number of economically active population. It is widely known as Junar of Sindhuli all over the country due to its delicious taste with highly nutritive constituents (MoAD, 2011).

The potentiality of growing sweet orange is very high so as to meet the target of production and to scale of the existing situation, the program has been launched namely 'One District One Product' (ODOP). It has the potentiality to export in international market but the production is in limited quantity. To meet the consumer's demand, the fruit is imported from neighboring countries like India and China in large quantities. It is most grown important fruit crop over the world which constitutes the bulk of global citrus fruit production (Reddy, 2011).

The total fruit production is expanding due to good governance, suitable climate and market demand but is still challenging due to traditional management practices (Kaini, 2013).Also, little or no irrigation facility is one of the major problems for the farmers due to which production is very nominal even with the availability of the appropriate climate and environment (Bibash, 2011). Beside it, there are still many growers who cannot adapt better technology to maintain and manage the farming. Most of the farmers are still unaware to diversify into other crops to spread agricultural risk (Aurora, 2002).

Prime Minister Agriculture Modernization Project (PMAMP), Junar Superzone is established in Sindhuli district which mainly works on Sweet orange research for the development of required suitable technology. Therefore, the main objective of the study was to identify the production and marketing scenario along with problems and possibilities. In gist, we aimed to analyze the economics of sweet orange in the study area.

\section{Material and Methods}

\section{Study Site}

Sindhuli district was selected purposively for the survey as it is well known for sweet orange production since long. The study was conducted in two VDCs of Sindhuli district: Tinkanya and Baseswor which lies in inner Terai of Nepal. The reason behind the selection is that it ranks in top position in area and production of sweet orange in Sindhuli district. The sweet orange farmers of the study site were the sampling population. Among the total growers, 60 of them were randomly selected from the list given from Prime Minister Agriculture Modernization Project (PMAMP), Junar superzone, Sindhuli.

\section{Research Instrument and Design}

The information from PMAMP, Sindhuli was helpful to understand the socio demographic status and sweet orange cultivation practice in the study area. Both primary and secondary source of data were used in exploring the information of the production and the status of sweet orange in the study site. The primary data were collected from faceto-face interview using semi-structured interview schedule to get valid and reliable data for the research. The information such as production, cost of price, production and marketing problems, strategies that could be adopted for it, grading and packaging procedure, income from sweet orange production, price determining, market information, involvement and support from any organization related data were collected. The secondary data were majorly collected from the publications of different organizations and institute related to sweet orange such as Central Bureau of Statistics (CBS), Ministry of Agricultural Development (MoAD), Prime Minister Agriculture Modernization Project (PMAMP), Nepal Agriculture Research Council (NARC), etc.

After the data collection, it was thoroughly checked for accuracy using triangulation method, and then it was coded and entered into the computer for analysis. The data were entered using MS Excel. These excel files were imported into SPSS software where the data were tabulated and analyzed.

\section{Economic Analysis}

Gross margin $=$ Gross return- total variable cost

Where,

Gross return $=$ price of sweet orange $\times$ total quantity sold

Total variable cost $=$ Summation of cost of all variable items

Benefit-cost analysis $=$ Gross return/total cost

\section{Ranking Of Production and Marketing Problems}

The ranking was done by Henry Garrett ranking method. The percentage position of each rank was obtained by using the formula then the rank obtained was converted to the score from the table given by Henry Garrett.

Percentage position $=\frac{(\mathbf{1 0 0}(\boldsymbol{R} \boldsymbol{i} \boldsymbol{j}-\mathbf{0 . 5})}{\boldsymbol{N} \boldsymbol{j}}$

Where,

$\mathrm{R}_{\mathrm{ij}}=$ Rank given for $\mathrm{i}^{\text {th }}$ item $\mathrm{j}^{\text {th }}$ individual

$\mathrm{N}_{\mathrm{j}}=$ Number of items ranked by $\mathrm{j}^{\text {th }}$ individual 


\section{Result and Discussion}

\section{Socio-Economic Characteristics of Sweet Orange Farmers}

The Table 1 demonstrate the results which revealed that both, male $(51 \%)$ and female $(49 \%)$ were engaged in farming of sweet orange. $67 \%$ of the respondents were economically active (16-59 years of age) while $10 \%$ belonged to economically inactive population (above 60 years of age). The household size on the survey area was on an average of 7 persons per household. The sampled society was dominant by $57 \%$ Janajati community followed by $32 \%$ Chhetri and $11 \%$ Dalits. The education level of surveyed people showed that $2 \%$ had bachelor degree, $12 \%$ had secondary education, $23 \%$ had received primary education, $8 \%$ were just literate while $55 \%$ of the respondents were illiterate. The $93 \%$ population was involved in agriculture as primary source of income while rest of the population was found involved in either service or wage labor. The average land holding was 0.37 hectare per household. None of the respondents had taken land in lease for the farming purpose.

Table 1: Population distribution based on various socioeconomic characteristics

\begin{tabular}{ll}
\hline Parameters & Percentage \\
\hline Gender & \\
Male & $51 \%$ \\
Female & $49 \%$ \\
Age & \\
$\quad$ <15 years & $23 \%$ \\
15-59 years & $67 \%$ \\
$\quad>60$ years & $10 \%$ \\
Education & \\
$\quad$ Illiterate & $55 \%$ \\
Literate & $8 \%$ \\
$\quad$ Primary & $23 \%$ \\
Secondary & $12 \%$ \\
Higher Secondary & $2 \%$ \\
Ethnicity & \\
Janajati & $57 \%$ \\
Chhetri & $32 \%$ \\
Dalits & $11 \%$ \\
\hline
\end{tabular}

\section{Summary Statistics}

Average family size of the sweet orange framers was 7 members. The average education level of the respondents was 3 years which indicates that high number of respondents were illiterate. The average land holding under sweet orange cultivation was 0.37 hectare per household. Average respondents have had 18 years of experience in sweet orange framing. In terms of income, the average family income was found to be Rs. 43,485 (Table 2).

\section{Farmers Visit to Extension Agent}

The figure shows that 36 respondents among all visit the extension service provider monthly whereas 17 respondents never visited the service provider. The respondents who visited to extension service provider said that they got to know some new ideas about the production practice from the visit.

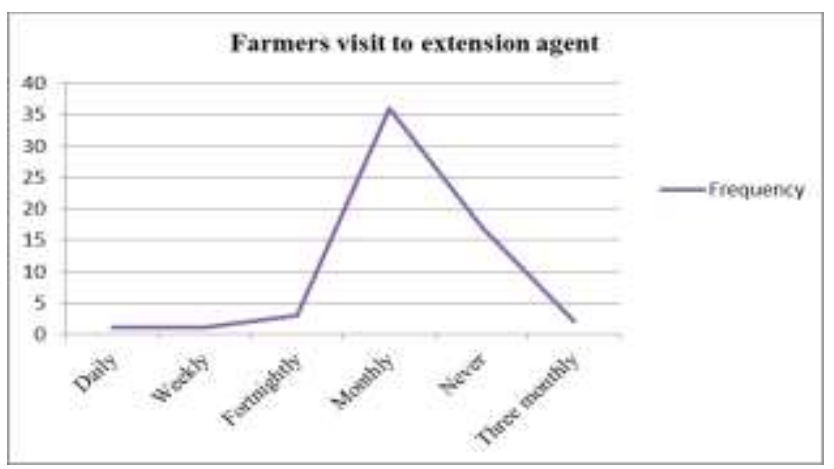

Fig. 1: Farmers visit to extension service provider [Source: Field survey, 2017]

\section{Training Received by The Sweet Orange Farmers}

The Fig. 2 shows that $75 \%$ of the respondents had taken training on sweet orange production. The respondents who took the training on sweet orange cultivation were found to have more knowledge and ideas about its farming in comparison to the respondents who never visited for any of the training.

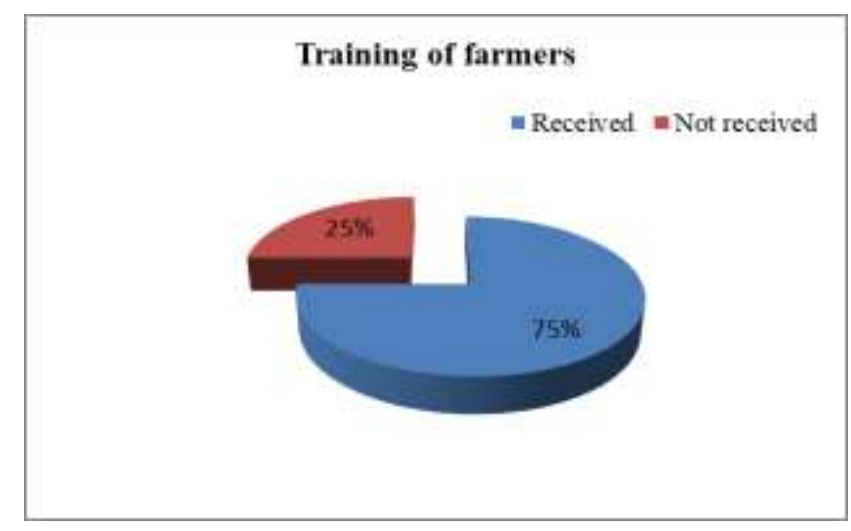

Fig. 2: Training received by farmers on citrus cultivation [Source: Field survey, 2017]

Table 2: Descriptive analysis of sweet orange farmers in Sindhuli district $(\mathrm{N}=60)$

\begin{tabular}{lcccc}
\hline Variable & Mean & S.D. & Min & Max \\
\hline Family size & 6.81 & 2.86 & 2 & 14 \\
Land holdings under sweet orange (ha.) & 0.37 & 0.248 & 0.05 & 1.5 \\
Farming experience (Years) & 18.1 & 11.9 & 1 & 40 \\
Family Income (Rs.) & 43,485 & 27410.22 & 800000 & 10000 \\
\hline
\end{tabular}

[Source: Field survey, 2017] 


\section{Cost Of Production and Benefit Cost Ratio}

We can observe in Table 3 that the cost attributing inputs for the sweet orange production such as seedlings, manures and fertilizers, pesticides, and intercultural operation are included as variable cost which is NRs.16199.86. The production of sweet orange $(\mathrm{kg} / \mathrm{ha})$ is $1981.83 \mathrm{~kg}$ with an average price of NRs. 36.65 per $\mathrm{kg}$. The gross margin is NRs. 56434.2 and benefit cost ratio is 2.81 which indicate it as a beneficial business.

Table 3: Cost of production of sweet orange and Benefit Cost ratio $(\mathrm{N}=60)$

\begin{tabular}{|l|l|}
\hline Particulars & Cost incurred \\
\hline Variable cost: (NRs/ha) & \\
\hline Seedlings & 8333.19 \\
\hline Fertilizers & 2961.67 \\
\hline Manure & 678.33 \\
\hline Pesticides & 2801.67 \\
\hline Intercultural operation & 1425 \\
\hline Total variable cost & $\mathbf{1 6 1 9 9 . 8 6}$ \\
\hline Total Fixed cost & $\mathbf{9 5 9 7 . 5}$ \\
\hline Total cost (NRs/ha) & $\mathbf{2 5 7 9 7 . 3 6}$ \\
\hline Production (Kg/ha) & 1981.83 \\
\hline Average price (NRs/kg) & 36.65 \\
\hline Gross return (NRs) & 72634 \\
\hline Gross margin (NRs) & 56434.2 \\
\hline B/C ratio & $\mathbf{2 . 8 1}$ \\
\hline
\end{tabular}

[Source: Field survey, 2017]

\section{Marketing Channel}

Marketing is simply determining the price of the product. The more the marketing channels, the more will be the price of the product and vice versa. Most of the farmers (45\%) in the study site sell their product to the wholesaler, $31 \%$ of the farmers sell to the local traders, and remaining $24 \%$ of them sell their product themselves.

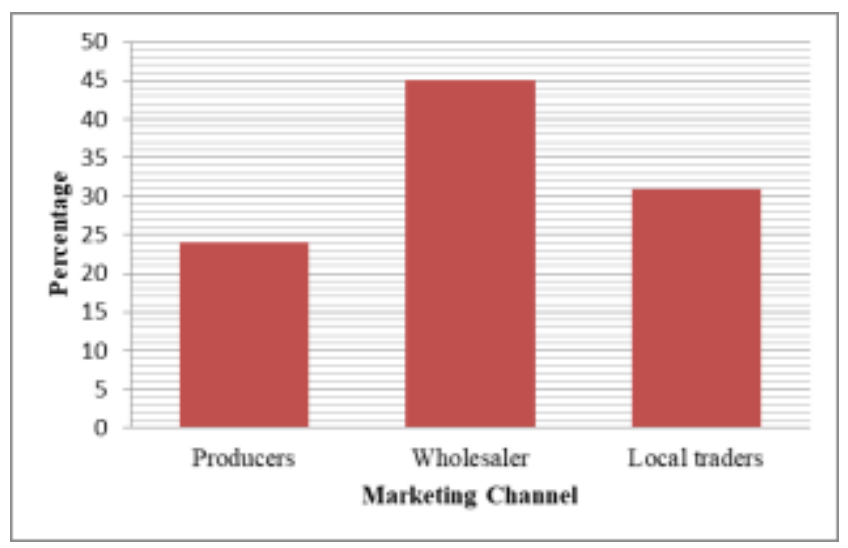

Fig 3: Marketing channels of sweet orange

[Source: Field survey, 2017]

\section{Production Problems of sweet orange growers}

There are various problems framers are facing in the production process resulting in the degradation of quality of fruit crop and also in the quantity production. The table 4 indicates insects as a major problem in the production of sweet orange followed by lack of irrigation and disease.
Lack of inputs and quality saplings along with cultivation skill are then found to be the other problems in production process.

Table 4: Ranking of production problems

\begin{tabular}{|l|l|l|}
\hline Problems & Average score & Ranking \\
\hline Insects & 42.44 & I \\
\hline Lack of irrigation & 36.04 & II \\
\hline Disease & 36.00 & III \\
\hline $\begin{array}{l}\text { Unavailability of inputs } \\
\text { in time }\end{array}$ & 28.60 & IV \\
\hline Lack of quality saplings & 22.75 & V \\
\hline Lack of cultivation skill & 14.34 & VI \\
\hline
\end{tabular}

[Source: Field Survey, 2017]

\section{Marketing Problems of Sweet Orange Growers}

There are various problems that hinders in the marketing of the products resulting in the loss both, monetarily and in the quality of the product. The problems are to be addressed so as to minimize it by adopting the technologies strategically. In Table 5, we can see the ranking of problems faced by the farmers based on their perception. According to them, difficulty in transportation is ranked as the major problem of marketing of sweet orange followed by lack of market price information and storage facility.

Table 5: Ranking of the marketing problems

\begin{tabular}{|l|l|l|}
\hline Problems & Average score & Rank \\
\hline Difficulty in transportation & 73 & I \\
\hline $\begin{array}{l}\text { Lack of market price } \\
\text { information }\end{array}$ & 56 & II \\
\hline Lack of storage facility & 44 & III \\
\hline Lengthy marketing facility & 28 & IV \\
\hline
\end{tabular}

Source: Field Survey, 2017

\section{Conclusion and Recommendation}

The productivity of the sweet orange in the study area is low even being a potential pocket area of sweet orange. It is due to following the traditional way of farming which lacks modernized and effective framing techniques. The attack of insects and rain-based farming seems to be the major hurdle in production process while lack of market knowledge and transportation facilities are the challenges in its marketing. The productivity could be increased if the constraints are addressed properly by the concerned authorities.

Based on the analysis of findings from the research survey, especially the constraints faced by farmers in production and marketing of sweet orange, major recommendations have been made:

- Policies are to be made to provide subsidies in agricultural inputs, equipment and seedlings 
required by farmers as it should be affordable for growers.

- Farmers should be encouraged to form a group.

- Plant protection training and information are to be provided to increase the quality and productivity of the product.

- Storage facility like low-cost cellar store should be organized to store such perishable fruits.

- Efficient method of irrigation technologies should be introduced to the location to minimize the irrigation problems.

- Research should be done to analyze and disseminate the market information to farmers.

\section{References}

Aurora (2002) Citrus Industry Development Strategy. Aurora Practical Solution Pt Ltd. National Library of Australia

Bibash (2011, January 4) Junar in Nepal. Retrieved from http://bibash-nepal.blogspot.com/2011/01/junar-innepal.html

Ghimire NP, Adhikari H, Jaishi M, Acharya BB and Adhikari KP (2006) Potentialities and Opportunities of Citrus in Ramechhap and Sindhuli Districts of Nepal. Retrieved from:

https://www.scribd.com/document/28209299/Potentialiti
es-and-Opportunity-of-Citrus-in-Ramechhap-andSindhuli-District-of-Nepal

Kaini BR (2013) Package of Practices for Junar Production and Post harvest Management. JICA and JCCU

MoAD (2011) Study Report on Status of Sweet Orange Cultivation and Processing Industries, Ministry of Agricultural Development, Government of Nepal.

MoAD (2016) Statistical Information on Nepalese Agriculture. Agribusiness Promotion and Statistics Division, Ministry of Agricultural Development, Government of Nepal.

Pandey G, Basnet S, Pant B, Bhattarai K, Gyawali B and Tiwari A (2017) An analysis of vegetables and fruits production scenario in Nepal. Asian Research Journal of Agriculture 20: $1-10$.

Reddy KV (2011) Production to Consumption Systems: Case Study of Sweet Orange Cultivation in Nalagonda District

Sefoka BT (2012) Sustainability of Sweet Orange Production in Fetakgomo Municipality: Case Study of Ga-Nkwana and Mohaletsi Community Projects. Retrieved from: http://www.gardenizly.co.za/dissertation_sefoka.pdf

Subedi P, Ranjit M and Poudel KP (2002) Report on Citrus decline research in the hills of Nepal, Rampur, Nepal

Tomiyasu Y, Verma SK and Thapa DB (1998) Citrus Cultivation in Nepal: A book in Nepali version, Published by Horticulture Devlopment Project. 